aphids in spite of heavy rains and low temperatures was remarkable, subsequent examinations showed them feeding up until about the first of November. Very few winged individuals were found. The oviparous females are brownish black in color, with a white line along the middle of the thorax. The antennæ are pale, with black tips.

The eggs are smooth and elongate, averaging $.12 \mathrm{~mm}$. in length by $.02 \mathrm{~mm}$. in breadth. They are of a pale yellow tinge when first laid, but in a few hours the color changes to a dark orange, and later to a shiny jet black.

\title{
TWO NEW SCHENDYLOID CHILOPODS FROM GUATEMALA.
}

By Ralph V. Chamberlin,

Museum of Comparative Zoölogy, Cambridge, Mass.

The interesting new chilopods described below are represented by single specimens taken from soil about the roots of the pacaya or salad palm (Chamædorea sp.) from Coban, Guatemala, at quarantine in Washington, D. C., January 29, 1920, by Messrs. W. B. Wood and H. L. Sanford and transmitted to me for identification from the United States Bureau of Entomology. In addition to the two chilopods, two diplopods were also found, these being Orthomorpha coarctata (Saussure) and Cleidogona sp., the latter being represented by an immature specimen which is possibly C. stolli Pocock.

\section{Sogolabis gen. nov.}

Labrum not free, forming an arc armed with an even series of teeth much as in, e. g., Adenoschendyla.

Claw of palpi of second maxillæ long, the margins smooth, neither pectinate or spined. Pleurosternal suture of second maxillæ complete, sharply marked, the pleurite extending forward to coxosternum.

No ventral pores present.

Coxopleural pores of pregenital segment small, simple, several on each side as in Escaryus.

Anal legs composed of six articles beyond coxopleura, without claw. 
Genotype: S. scapheus, sp. nov.

A genus differing from all other schendylids excepting Escaryus and Eucratonyx in having several coxopleural pores on each side. From these genera it differs in not having the labrum free, in the non-pectinate claw of the second maxillæ, the absence of chitinous lines from the prosternum, etc. It departs from all other known schendylids in having the anterior margin of the prosternum and the femuroid of prehensors armed.

\section{Sogolabis scapheus sp. nov.}

Pale fulvous, with the head and prehensorial segment orange.

Head longer than wide in about ratio 13:8. Sides of head nearly parallel from the oblique caudal corners forward to in front of the middle, then slightly converging. Anterior margin convex, not notched at middle. Posterior margin truncate. No frontal suture.

Antennæ filiform, the last joint about equalling the two preceding taken together.

Prebasal plate not exposed. Exposed portion of basal plate short, broad. Claws of prehensors when closed surpassing the head, attaining the distal end of the first article of the antennæ. Anterior margin of prosternum armed with two strongly chitinized teeth which in the type are broader than high, rounded. Femuroid of prehensors armed toward distal end with a subconic but distally rounded tooth of moderate size. Next two joints unarmed. Claw armed at base with a larger, strongly chitinous, tooth which is conical, distally acute.

First legs a little shorter and more slender than the second, the others nearly uniform in length and thickness to the penult inclusive.

No ventral pores detected in the type.

Sternite of pregenital segment of moderate width, nearly equal in width and length, trapeziform, the sides and posterior margin straight. Each coxopleura with five simple pores.

Last legs longer than the penult; with few hairs; last article clawless, distally rounded.

Anal pores present.

Number of pairs of legs in female, thirty-nine.

Length, $8 \mathrm{~mm}$. 
Schendylellus gen. nov.

Median arc of labrum armed with strongly chitinous true teeth with distinct roots.

Claw of palpi of second maxillæ abortive, in the genotype appearing only as an extremely minute rudiment or point.

Ventral pores present on sternites, these arranged in a narrow transverse band across plate at level of major setæ.

Coxopleuræ of pregenital segment each with two homogeneous glands.

Genotype,-S. hodites, sp. nov.

This genus is obviously close to Schendyla, but differs in the abortive claw of the palpi of the second maxillæ and in the arrangement of the ventral pores, these in Schendyla forming a median area as long as or longer than wide and commonly quadrate or sub-circular in outline.

\section{Schendylellus hodites sp. nov.}

General color pale fulvous, head and prehensors dilute orange.

Head widest toward posterior end, narrowing forward, the anterior and posterior margins truncate. Prebasal plate not exposed.

Antennæ filiform, the last four articles preceding the ultimate in the type much shortened, the last three of these about equalling the ultimate in length.

Median arc of labrum with ten, not crowded, teeth, or near that number.

Claws of prehensors when closed a little surpassing the anterior margin of head but not attaining the distal end of first antennal article. Prehensors in dorsal view also a little exposed toward base. Claw armed at base with a very small but distinct tooth, the other joints unarmed. Anterior margin of prosternum unarmed, smooth.

First legs a little shorter and more slender than the second, the others of nearly uniform length and thickness to the penult inclusive.

Ventral pores beginning on the first sternite and present on all to the thirty-fourth segment, $i$. e., to the penult pediferous. On the first plate they are few, only about six in number, these being in an irregular transverse row at middle of plate. On the succeeding sternites the pores are more numerous and form a narrow transverse band extending on each side well toward the lateral margin 
at level of posterior major marginal seta. Pores fewer again on the last several plates.

Sternite of pregenital segment broad, trapeziform. Coxopleural glands two on each side, simple, the pores covered by the sternite.

Last legs in the male clavately enlarged, scarcely exceeding the penult in length. Unfortunately these became detached and lost in the course of the clearing of the specimen for mounting for microscopical study.

Number of pairs of legs in the male, thirty-five.

Length of the type, $7.5 \mathrm{~mm}$.

It is thought best not completely to dissect the head of the single type specimen at this time. Hence mandibles and maxillæ are not described in detail.

\section{PROCEEDINGS OF THE CAMBRIDGE ENTOMOLOGICAL CLUB.}

At the meeting of the Cambridge Entomological Club February 10 , on account of the difficulties of travel only 14 persons attended. The meeting voted to approve the publication, in Psyche, of abstracts of the proceedings of the Club meetings and of local entomological news.

Prof. C. T. Brues read some notes on distribution of South African Hymenoptera, several of which occur or have their nearest relatives in South America or India rather than in more northern parts of Africa. Professor Wheeler read a satire on human society from the supposed standpoint of a member of a colony of Termites. This paper is published in the Scientific Monthly of February, 1920.

Mr. Varás showed a beetle with a branched tibia of one of the third pair of legs, and this was followed by discussion of abnormal insert legs in general.

At the meeting of March 9, Mr. J. H. Emerton read some notes on last season's collections of spiders in Canada, including specimens from the Rocky Mountains, near Banff, Pribiloff Islands, Klondike Valley, Gaspe, St. John's, Newfoundland, Ontario and Quebec.

Mr. Frost read notes on the habits, occurrence and classification of several Coleoptera which he had found in Maine-Scythropus elegans, cicendela elegans and cicendela spreta Lecr. The latter species he thought to be the same as C. limbalis Klug. 

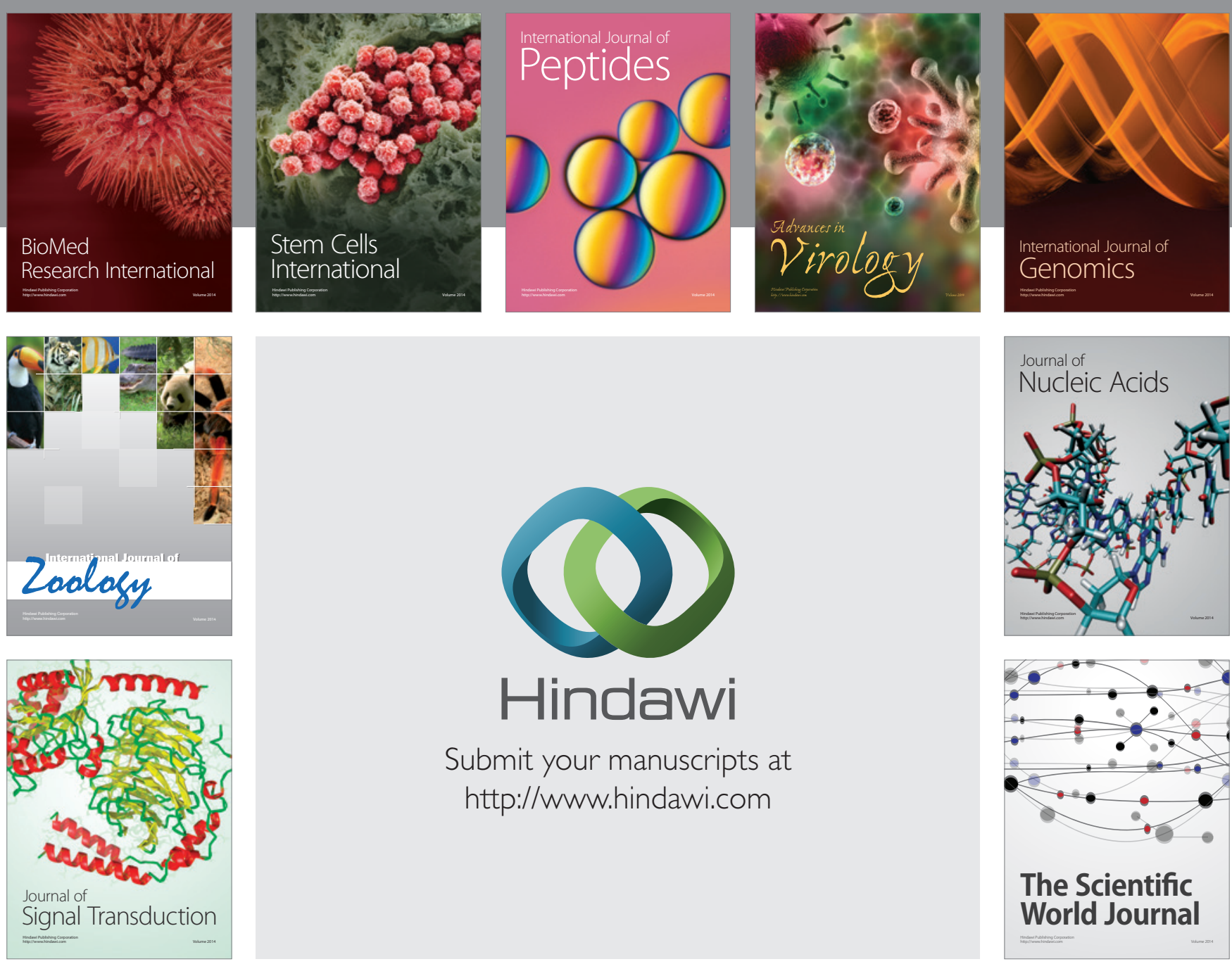

Submit your manuscripts at

http://www.hindawi.com
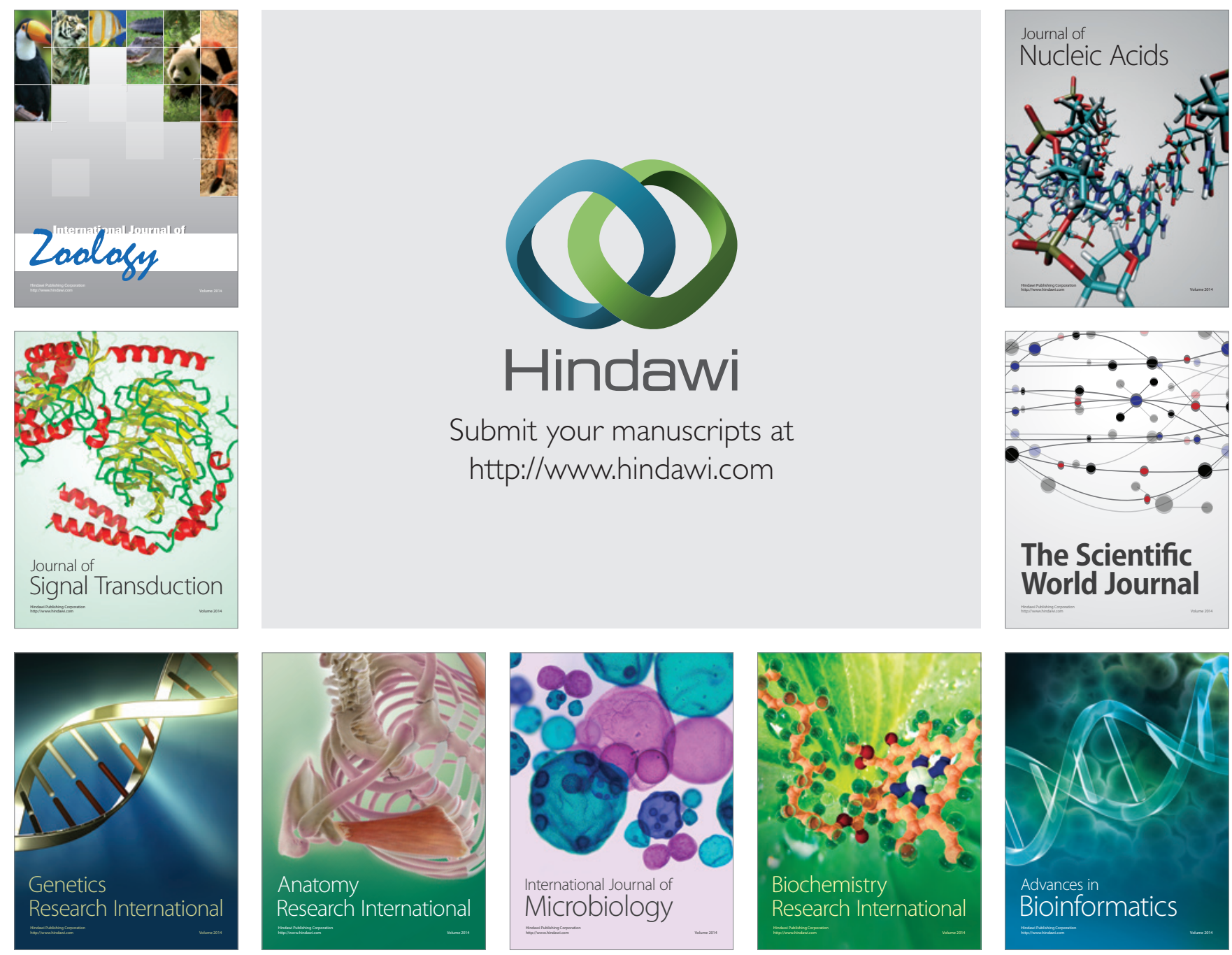

The Scientific World Journal
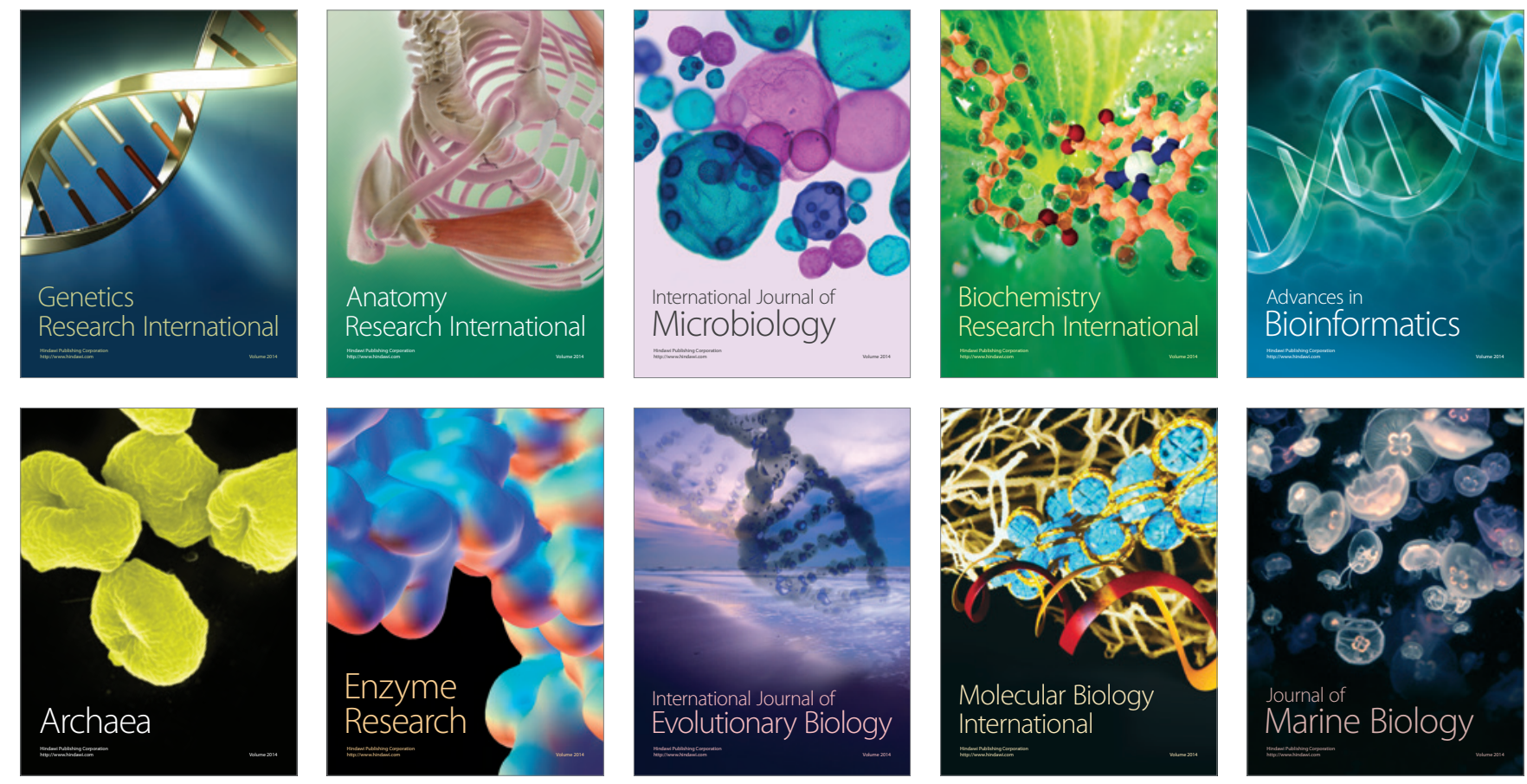